\title{
SCIENTIFIC COMMUNICATIONS
}

\section{A NEW SECTION THROUGH THE SUB-KARELIAN UNCONFORMITY AT NIINIVAARA, SAVO, EASTERN FINLAND}

\author{
ADRIAN F. PARK
}

\begin{abstract}
Bull. Geol. Soc. Finland 60, Part 1, 67-73, 1988.
Key words: stratigraphy, skarn, unconformities, deformation, Precambrian, Niinivaara, Kaavi, Finland.

Adrian F. Park: Department of Geology, University of Glasgow, Glasgow G12 8QQ, Scotland, U.K.
\end{abstract}

\section{Introduction}

Construction work on the Kaavi-Juuka road in the parish of Kaavi, Savo, produced a series of temporary rock cuttings around the village of Niinivaara (Figs. 1, 2). These temporary outcrops illustrate a number of important features concerning the nature of the sub-Karelian unconformity and the extent and nature of Svecokarelian tectonic reworking of the Archaean basement gneisses.

The sub-Karelian unconformity in the parish of Kaavi has a complex outcrop pattern, largely due to the effects of thrusted interdigitation of basement gneiss with Karelian metasediment during the second phase of Svecokarelian deformation $\left(\mathrm{D}_{2}\right)$ (Fig. 1).

Huhma $(1971,1975)$ recognised two major subdivisions in the Karelian metasediments of the Sivakkavaara map sheet; Kalevian quartzofeldspathic mica schist and gneiss, dominated by metapelite and metapsammite with only minor graphitic schist intercalations, and metamor- phosed Jatulian ortho-quartzites with sporadic amphibolite horizons. Arkosites and calc-silicate skarns occur in both units, locally comprising up to $50 \%$ of the Jatulian, but restricted in the Kalevian to narrow zones along contacts with basement gneiss around Niinivaara (termed »basal arkosite», Fig. 1).

In the local Jatulian unit, metaquartzitearkosite-calc-silicate skarn rocks form a mineralogical spectrum, dependant on modal variation in feldspar and quartz. The calc-silicate skarn rocks represent a quartz-deficient end member, containing diopside and/or tremolite plus quartz, or when quartz is absent, clino-zoisite, grossular and carbonate, in a matrix rich in calcic plagioclase and microcline. Scapolite is an occasional accessory phase.

The basal Kalevian arkosite also includes calcsilicate skarn with the same mineral assemblage, occurring as an impersistent layer along the micaschist-basement gneiss contact from the neighbourhood of Niskalampi southward for some $5-6 \mathrm{kms}$ until the contact is obscured by the 


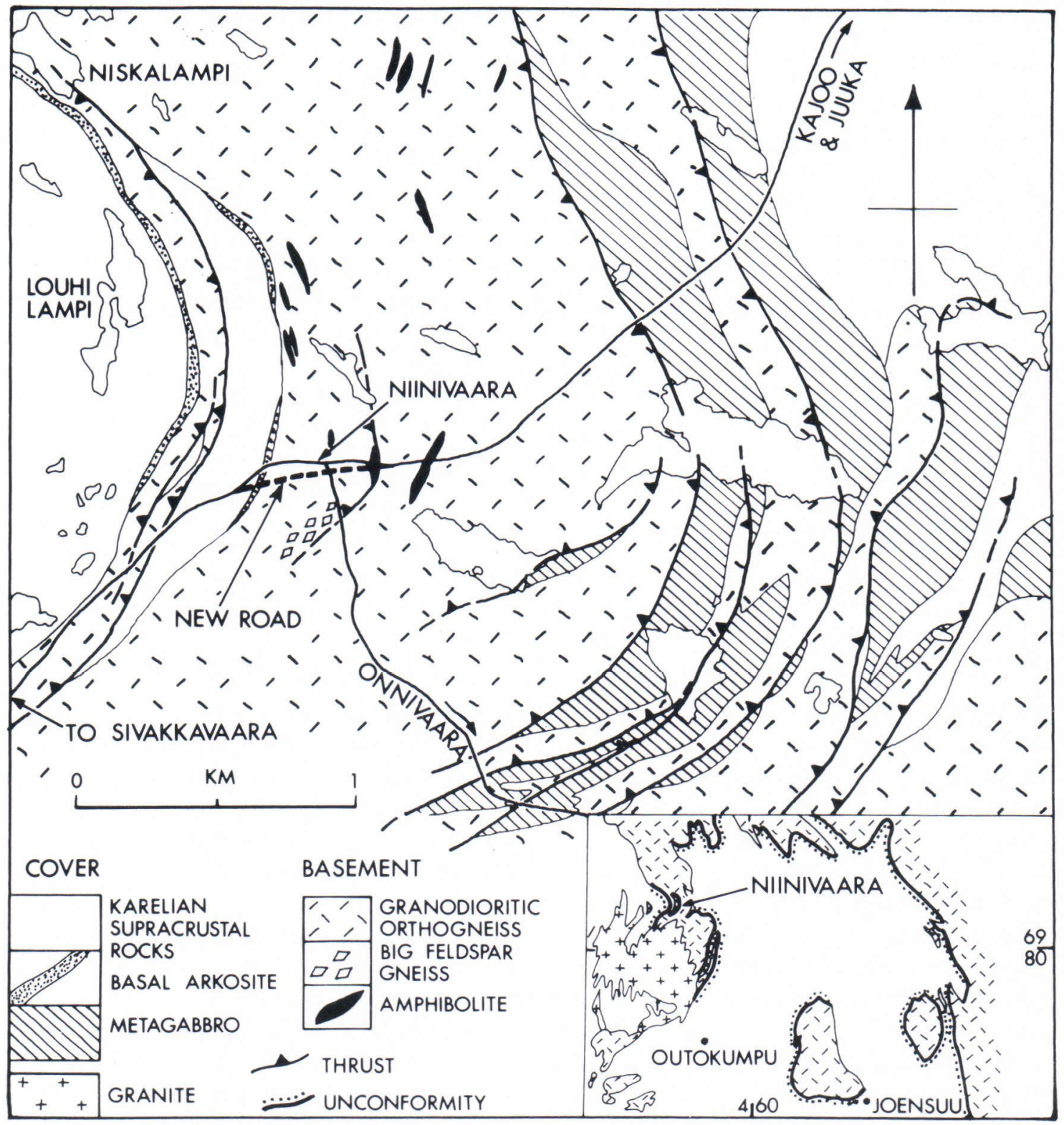

Fig. 1. Geology of the area around Niinivaara with the location of the new road cuttings. After Huhma (1971) and Park and Bowes (1983). (Inset) Outline geological map of part of N. Karelia and Savo showing the location of Niinivaara and the disposition of the sub-Karelian unconformity.

Maarianvaara granite (Fig. 1). Like the contact itself, the basal arkosite outcrop is repeated by a thrust (Park and Bowes 1983). It differs notably from the Jatulian examples, in containing more microcline, so that in modal mineralogy a spectrum is evident between typical Kalevian metapsammite and basement gneiss. Where basal arkosite and the basement gneiss are both modally identical, and intensely deformed they are difficult to distinguish from each other. 


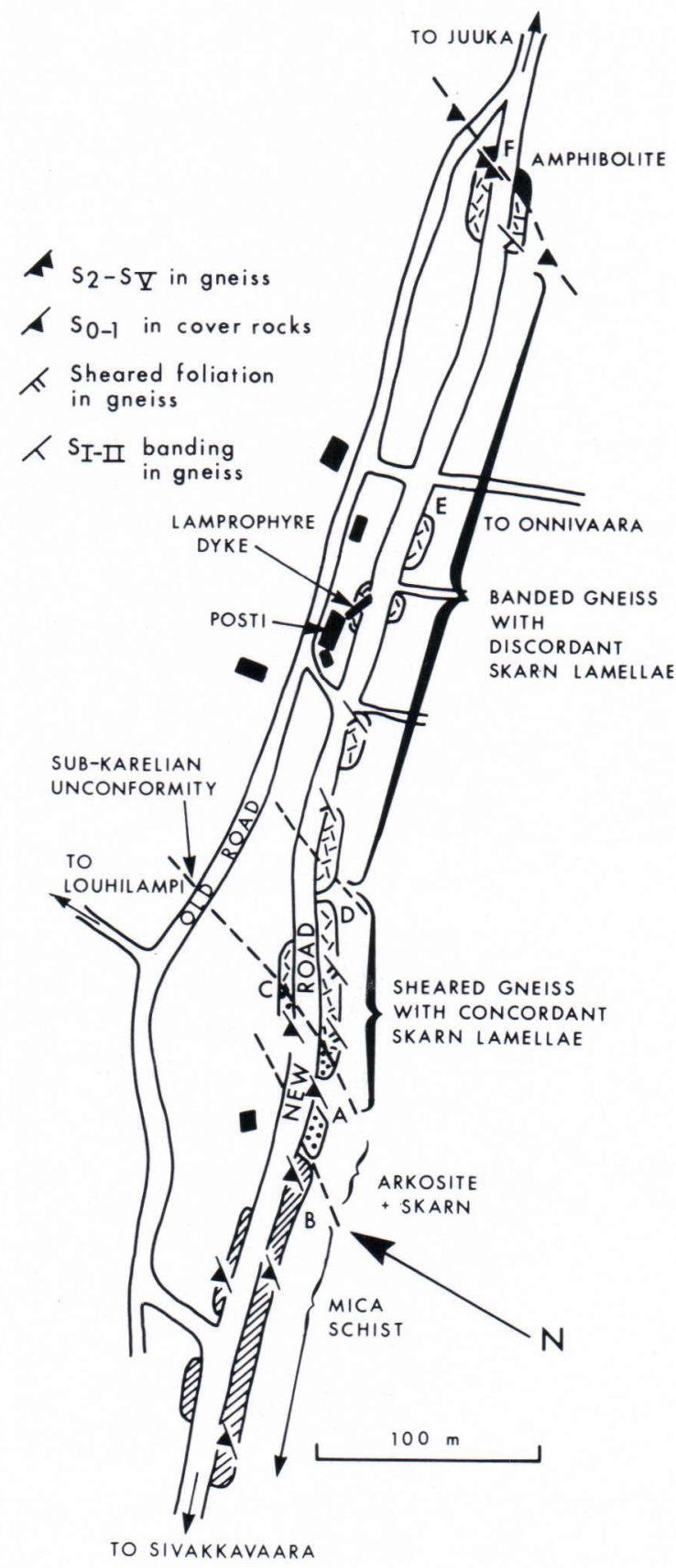

Fig. 2. Sketch map of the cuttings on the new road at Niinivaara, Kaavi commune, showing the temporary exposures visible in July 1986. A-F are locations of photographs in Figure 3.

The local basement gneiss is a grey, coarse, two feldspar (orthoclase + andesine), biotite ortho- gneiss with variable quartz content and occasional hornblende. When strongly sheared, adjacent to $\mathrm{D}_{2}$ thrusts the orthoclase is replaced by microcline, muscovite may appear, and hornblende is locally abundant. Migmatite is commonly stromatic, although agmatitic developments are locally preserved in amphibolite bodies. These latter consist of hornblende and labradorite-andesine but have been transformed into phyllonitic biotite schists near $\mathrm{D}_{2}$ thrust planes (Figs. 2, 3f).

Fabric development in both cover and basement rocks was described by Park and Bowes (1983). In the basement gneisses, the strong, penetrative foliation that dominates most outcrops is termed $\mathrm{S}_{\mathrm{I}-\mathrm{II}}$. It is a composite fabric including the main biotite \pm hornblende growth and the stromatic migmatite. Earlier relics include the boundins of amphibolite with agmatitic granitic neosome and intrafolial folds. Patches of a megacrystic, porphyroblastic granite (»big feldspar gneiss») developed at this stage or earlier (see Park and Bowes 1983).

\section{Deformation in Archaean basement rocks}

A number of later folding phases $\left(\mathrm{D}_{\mathrm{III}-\mathrm{IV}}\right)$ deformed the $\mathrm{S}_{\mathrm{I}-\mathrm{II}}$ foliation, and related fabrics are also developed, but none are penetrative on anything but a local scale, and none are welldeveloped in the immediate vicinity of Niinivaara.

A series of mylonite-phyllonite zones are developed locally, in which the $\mathrm{S}_{\mathrm{I}-\mathrm{II}}$ foliation has been reworked by grain-size reduction. Local hydration at high temperature produced muscovite by the breakdown of $\mathrm{K}$-feldspar, the inversion of orthoclase to microcline, a strong biotite schistosity $\left(\mathrm{S}_{\mathrm{V}}\right)$ particularly in amphibolites, and a rodded augen texture in the »big feldspar gneiss». A pronounced hornblende lineation developed parallel to a strong rodding produced by the deformation of earlier pegmatite veins $\left(\mathrm{L}_{\mathrm{v}}\right)$. 

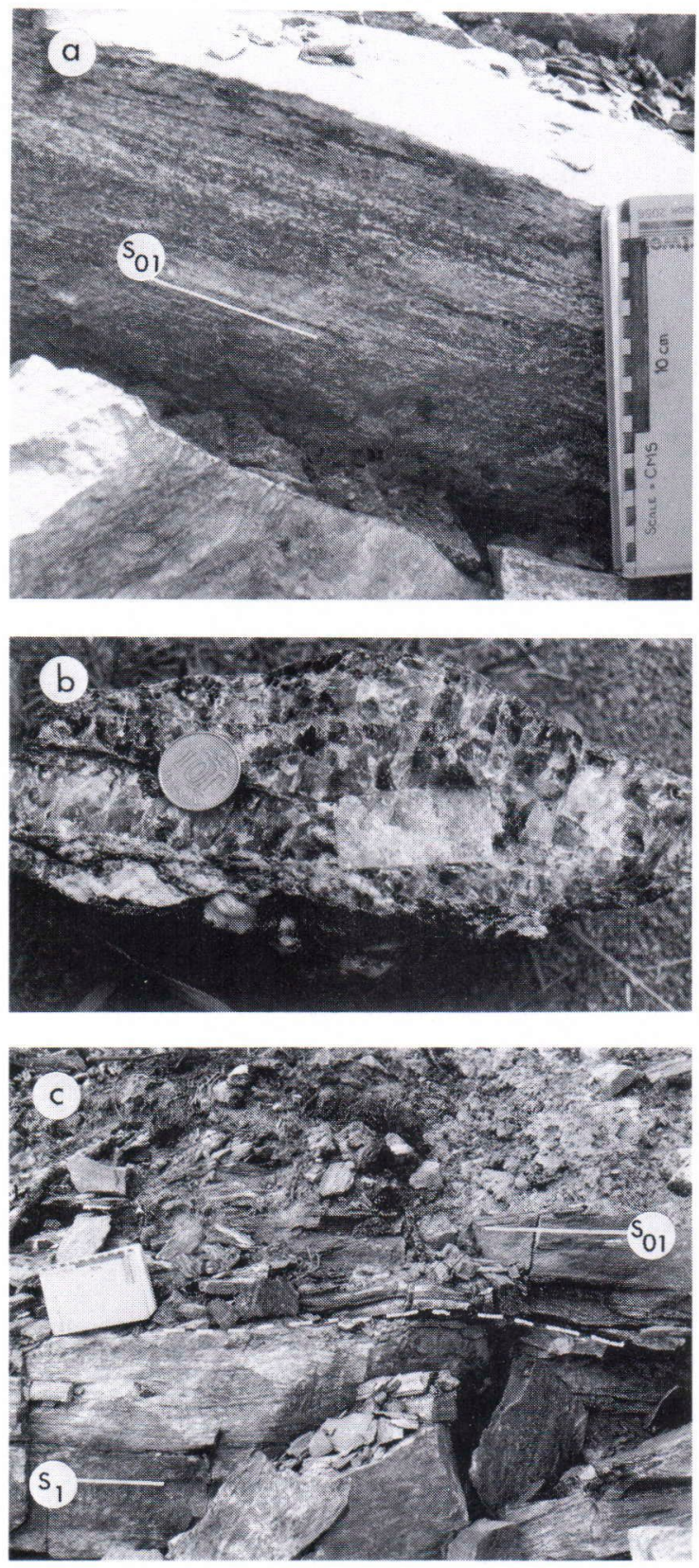

Fig. 3. Rocks in the Niinivaara road cuttings (for locations see Fig. 2). a. Arkosite with the composite $\mathrm{S}_{0-1}$ fabric and dark calc-silicate skarn lamellae. b. Folded quartz vein with apatite crystal and biotite selvage with scapolite (white), from pelitic mica schist. 10 pennia coin - scale (loose block). c. The sub-Karelian unconformity with $\mathrm{S}_{0-1}$ bearing skarniferous arkosite above, and sheared ( $\mathrm{S}_{1}$ bearing) basement gneisses beneath. d. Sheared $\left(S_{1}\right.$ bearing) basement gneiss with concordant skarn lamellae with »feldspathised» microcline-rich margins. e. Discordant skarn vein with »feldspathised» microcline-rich margin in coarse $\left(\mathrm{S}_{1-11}\right.$ bearing) basement gneiss. f. $\mathrm{D}_{\mathrm{v}}\left(\mathrm{S}_{\mathrm{v}}\right)$ phyllonite zone marking a thrust zone cutting $\mathrm{S}_{I_{-11}}$ dominated basement gneiss. The rock beneath the thrust is amphibolite.
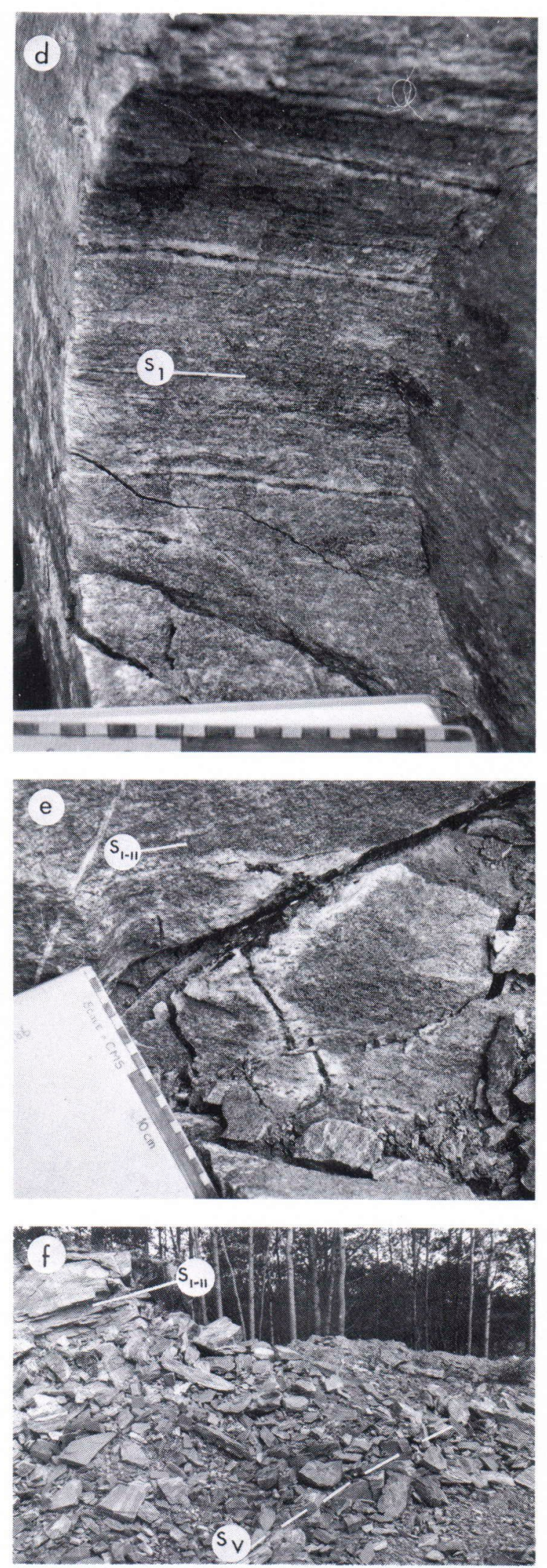


\section{Deformation in Proterozoic cover rocks}

In the metasediments of the cover, two deformation events produced two sets of folds and fabrics that dominate the rocks and their outcrop patterns. Around Niinivaara, the earliest fabric $\left(\mathrm{S}_{1}\right)$ is a metamorphic segregation banding parallel to primary lithological layering $\left(\mathrm{S}_{0}\right)$, only rarely is $\mathrm{S}_{1}$ seen in an axial planar relationship to isoclinal folds $\left(\mathrm{F}_{1}\right) \cdot \mathrm{D}_{2}$ deformation produced tight, asymmetrical folds, overturned towards the east. $\mathrm{S}_{2}$ is an axial planar schistosity usually derived by recrystallisation and orientation of biotite already extant in the $S_{1}$ segregations. The axial planes of $F_{2}$ folds and $S_{2}$ fabric are often parallel to the overturned limbs, in which $D_{2}$ slides or thrusts are occasionally located. These $\mathrm{D}_{2}$ slides demonstrably cut the basement-cover interface, and coincide with the $\mathrm{D}_{\mathrm{V}}\left(\mathrm{S}_{\mathrm{V}}\right)$ phyllonite zones in the gneisses.

\section{Niinivaara road cuts}

One and a half kilometres of discontinuous rock cuttings centred on Niinivaara post office expose a nearly continuous section through the Kalevian mica schist-basement gneiss contact (Fig. 2). The contact zone contains flaggy metapsammite (no top seen) underlain by 2 metres of biotite-rich metapelite containing folded quartz veins with traces of $\mathrm{K}$-feldspar, apatite, scapolite and iron sulphide (Fig. 3b). This is underlain by the $2.5 \mathrm{~m}$. thick basal arkosite which also contains thin layers of black schist, a biotite-sulphide rich schist, usually present as lamellar partings, although one exceptional layer attains $10 \mathrm{cms}$ in thickness. Calc-silicate skarn layers, dominated by green diopside and tremolite occur throughout (Fig. 3a). The unconformity is a sharp, though not very distinct boundary (Fig. 3d), underlain by a fine grained, banded, quartzofeldspathic gneiss with impersistent, concordant skarn layers similar to those in the arkosite, but fringed instead by narrow feldspathized (microcline) rims (Fig. 3d). This strongly sheared gneiss grades over 10-20 m into a coarse, banded gneiss with distinct, stromatic, leucogranitic neosome. The skarn persists as sporadic veins discordant to the $\mathrm{S}_{\mathrm{I}}$ foliation through the rest of the section, still showing feldspathized rims (Fig. 3e).

In the road cuttings, unsheared basement gneiss is rather homogeneous, but at the extreme eastern end of the new exposures an amphibolite body has been attenuated along the margin of a biotite-rich amphibole phyllonite (Fig. 3f). This phyllonite forms a zone $1-2 \mathrm{~m}$ thick, slightly discordant to the $\mathrm{S}_{\mathrm{I}-\mathrm{II}}$ foliation of the gneisses. It strikes under the fields to the south west, aligned with the mylonite at the base of the »big feldspar gneiss» exposure on the Onnivaara road. These occurrences mark the line of a $D_{2} / D_{V}$ thrust plane.

\section{Interpretation}

Two shear zones cross these road cuttings: one, interpreted as a $D_{2} / D_{V}$ thrust, lies at the eastern end, marked by a $1-2 \mathrm{~m}$ thick phyllonite, the other coincides with the c. $10 \mathrm{~m}$ thick zone of sheared basement gneiss along the unconformity and the basal arkosite. The shearing along the unconformity has firstly rotated the $\mathrm{S}_{\mathrm{I}-\mathrm{II}}$ foliation in the basement gneiss into conformity with the contact and $\mathrm{S}_{0-1}$ in the cover rocks, and transposed the skarn veins into parallelism. Away from this contact these veins can be seen to have been originally discordant.

Though thoroughly recrystallised the calcsilicate skarn developments closely resemble palaeo-regoliths recorded elsewhere from the subKarelian unconformity in N. Karelia (Gaál et al. 1975; Pekkarinen 1979). These characteristically contain veins rich in calc-silicates, quartz and carbonate, with kaolinized, or white mica rich margins. At Niinivaara the pervading metamorphic conditions (c. $600^{\circ} \mathrm{c}, 2-4 \mathrm{~kb}-$ Park 1983 ) would have caused the recrystallisation of 

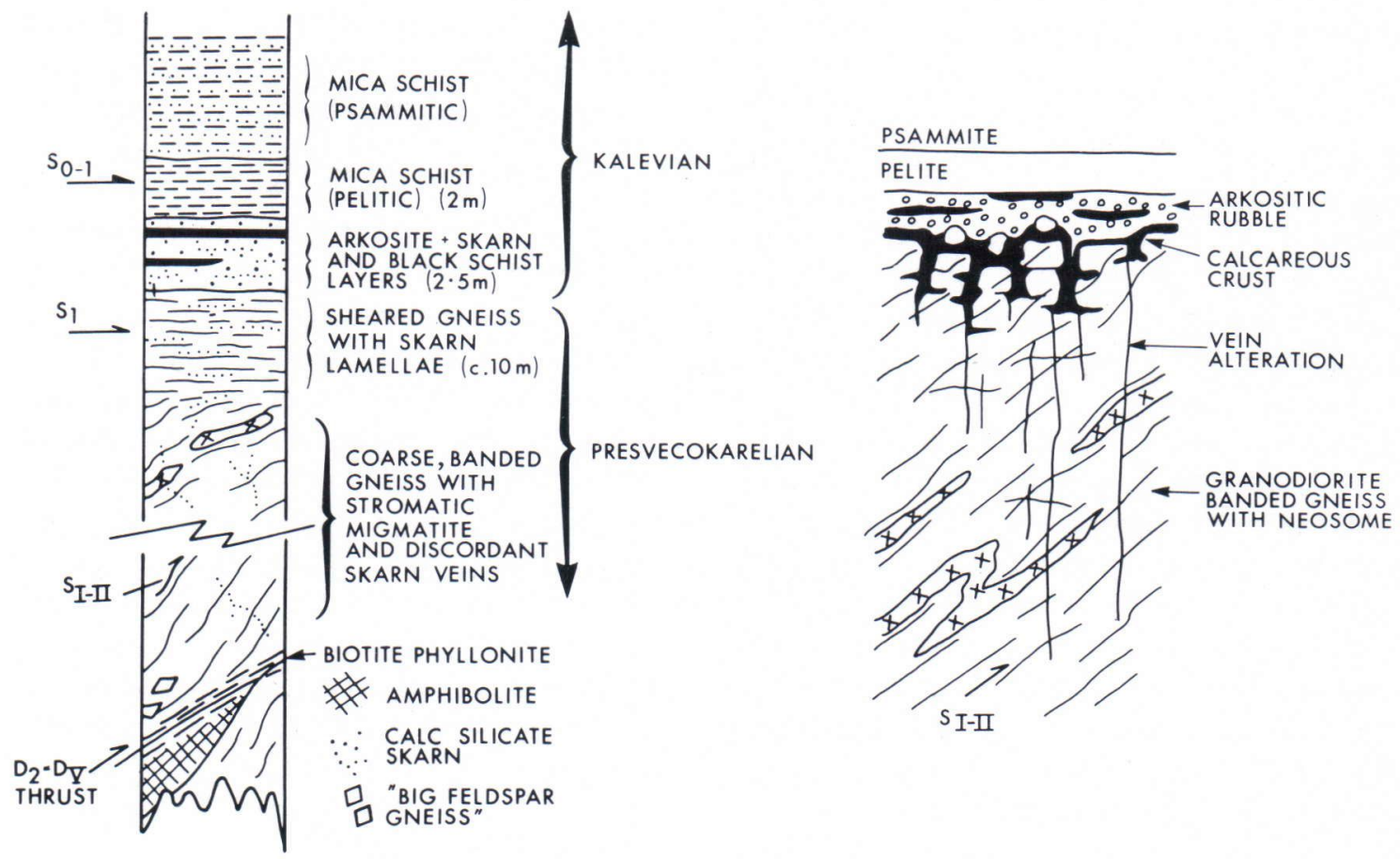

Fig. 4. Section through the sub-Karelian unconformity in the road cuttings at Niinivaara with an interpretative reconstruction of the original relationship (not to scale).

these assemblages as calc-silicate skarn free of quartz and carbonate, with microcline-rich wall rock.

Under appropriate conditions, weathering of Archaean basement gneisses could have yielded a regolith containing saprolitic, feldspar-rich rubble with variable amounts of quartz, with irregular layers or patches of carbonate or calc-silicate material, representing original calcified crusts, caliche or calcrete zones. Accordingly, the calcsilicate skarn-bearing arkosite, with its basement gneiss mineralogy is interpreted as a recrystallised and sheared palaeo-regolith where originally discordant calcareous patches are now concordant.

\section{Conclusions}

1. Svecokarelian $\mathrm{D}_{2}$ deformation was the only Proterozoic event to have substantially deformed Archaean basement at Niinivaara, recognised as discrete, narrow zones of reworked gneiss and amphibolite, 1-2 m thick, adjacent to thrusts.

2. Svecokarelian $D_{1}$ deformation was restricted to shear strain at the basement-cover interface, possibly enhanced due to regolith development.

3. A regolith was developed in Archaean gneiss at Niinivaara, and was directly overlain by Kalevian sediments. This implies that Jatulian sediments were eroded off prior to this, or were never deposited in this locality.

Acknowledgements. The author's work in Finland was supported by a grant from the University of Glasgow Research Support Fund. Erkki Luukonen is thanked for his comments on an early draft of this article, and the comments and criticisms of Jukka Marmo and Peter Ward as referees greatly assisted revision. 


\section{References}

Gaal, G.; Koistinen, T. J. \& Mattila, E., 1975. Tectonics and stratigraphy in the vicinity of Outokumpu, North Karelia, Finland. Geol. Surv. Finland, Bull., 271.

Huhma, A., 1971. Pre-Quaternary rocks, Sheet 4311 Sivakkavaara. Geological map of Finland 1: 100000.

—, 1975. Precambrian Rocks of the Outokumpu, Polvijärvi and Sivakkavaara map sheets (English Summary). Geological map of Finland 1: 100 000, Explanation to the maps of Outokumpu, Polvijärvi and Sivakkavaara.

Park, A. F., 1983. Sequential development of metamorphic fabric and structural elements in polyphase deformed ser- pentinites in the Svecokarelides of eastern Finland. Trans. R. Soc. Edinburgh Earth Sci., 74, 33-60.

— \& Bowes, D. R., 1983. Basement-cover relationships during polyphase deformation in the Svecokarelides of the Kaavi district, eastern Finland. Trans. R. Soc. Edinburgh Earth Sci., 74, 95-118.

Pekkarinen, L. J., 1979. The Karelian formations and their depositional basement in the Kiihtelysvaara-Vartsila area, east Finland. Geol. Surv. Finland, Bull., 301.

Received January 26, 1987

Revised and accepted February 29, 1988 